\title{
Development and Validation of RP-HPLC Method for the Simultaneous Estimation of Paracetamol and Flupirtine Maleate in Pharmaceutical Dosage Form
}

\author{
*Nagaraju Pappula and Poornima Chintala \\ Department of Pharmaceutical analysis, Hindu College of Pharmacy, Guntur, A.P-522002, India
}

\begin{abstract}
Objective: To develop and validate a simple, efficient and reproducible RP-HPLC method for the simultaneous determination of paracetamol and flupirtine maleate in bulk and in pharmaceutical formulations. Materials and Method: The chromatographic analysis was performed on a Thermo BDS hypersil $\mathrm{C}_{18}(250 \times 4.6 \mathrm{~mm}$ i.d, $5 \mu)$ column in isocratic mode using water: methanol $(\mathrm{pH}$ was adjusted to $3.35 \pm 0.02$ with ortho-phosphoric acid) in the ratio of $50: 50 \mathrm{v} / \mathrm{v}$ as eluent. The flow rate was $1 \mathrm{ml} / \mathrm{min}$ and eluent was detected at $250 \mathrm{~nm}$. The retention time of paracetamolandflupirtine maleate were 3.5 and $5.4 \mathrm{~min}$, respectively. Results: The linear dynamic range was $650-1950 \mu \mathrm{g} / \mathrm{ml}$ and $200-600 \mu \mathrm{g} / \mathrm{ml}$ for paracetamol and flupirtine maleate, respectively. Percentage recoveries for paracetamol and flupirtine maleate were 100.50 and $99.76 \%$, respectively. Conclusion: All the analytical validation parameters were determined and found in the limit as per ICH guidelines, which indicates the validity of the method. The developed method is also found to be precise and robust for the simultaneous determination of paracetamol and flupirtine maleate in tablet dosage forms..
\end{abstract}

Key words: Accuracy, flupirtine, paracetamol, validation.

\section{INTRODUCTION}

Paracetamol or acetaminophenis a widely used over-the-counteranalgesic (pain reliever) and antipyretic (fever reducer). It is classified as a mild analgesic. It is commonly used for the relief of headaches and other minor aches and pains and is a major ingredient in numerous cold and flu remedies. In combination with opioid analgesics, paracetamol can also be used in the management of more severe pain such as post-surgical pain and providing palliative care in advanced cancer patients. Chemically paracetamol is $\mathrm{N}$-(4-hydroxyphenyl) acetamide [Figure 1]. It is official in Indian Pharmacopoeia, ${ }^{1}$ British Pharmacopoeia ${ }^{2}$ and United States Pharmacopoeia. ${ }^{3}$

Flupirtinemaleate ${ }^{4}$ is a non-opioid centrallyacting analgesic agent, structurally dissimilar from other analgesics. It is used as an analgesic for acute and chronic pain, in moderate to severe cases. Its muscle relaxant properties make it popular for back pain and other orthopaedic uses, but it is also used for migraines, in oncology, postoperative care, and gynaecology. It is a pyridine derivative with a chemical name of ethyl \{2-amino6-[(4-fluorobenzyl)amino]pyridin-3-yl\} carbamate [Figure 2].

Literature survey reveals a few spectrophotometric and bioanalytical methods for the estimation of both drugs as a single component and in combination with other drugs. ${ }^{510}$ However no method has been reported for analysis of these drugs in combined dosage form. The objective of present work is to develop simple, rapid and precise RP-HPLC method for the estimation of paracetamol and flupirtine maleate in combined tablet dosage form.

\section{MATERIALS AND METHODS}

\section{Reagents and chemicals}

Paracetamol and flupirtine maleate reference substances are gifted by Lara Drugs
Submission Date : 17-06-13 Revision Date : :22-09-14 Accepted Date :06-11-14

DOI: $10.5530 /$ ijper.48.4s.5 Correspondence Address Prof . Nagaraju $P$,

Associate professor,

Department of Pharmaceutical analysis

Hindu College of Pharmacy, Guntur, A.P-522002, India Email: pappulanagaraju@ gmail.com

Mobile: 09985304304

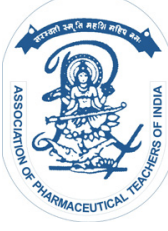

www.ijper.org 


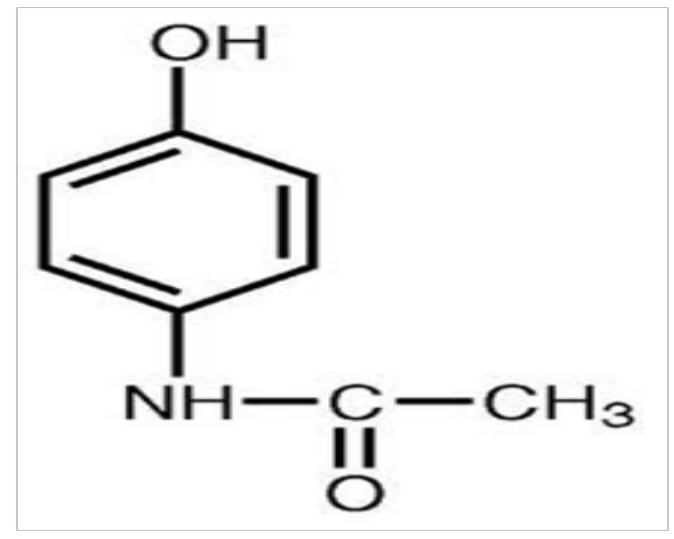

Figure 1: Structure of paracetamol

Pvt Limited, Hyderabad, India. Tablet dosage forms (KETOFLAM-P, LupinMaxter, Mumbai) were procured from the local market, each tablet containing 325 $\mathrm{mg}$ of paracetamol and $100 \mathrm{mg}$ of flupirtinemaleate. HPLC grade water and Methanol were purchased from E.Merck (India) Ltd., Mumbai. Ortho-phosphoric acid of AR Grade were obtained from S.D. Fine Chemicals Ltd., Mumbai.

\section{Instumentation}

The HPLC system consisted of Waters Alliance 2695 seperations module, integrated with Auto Sampler and equipped with Waters 2998 Photodiode Array Detector. The output of signal was monitored and integrated using waters Empower 2 software.

\section{Chromatographic conditions}

Thermo BDS hypersil $\mathrm{C}_{18}$ column $(250$ x $4.6 \mathrm{~mm}$ i.d, $5 \mu)$ was used for separation. The mobile phase containing water and methanol (adjusted to $\mathrm{pH} 3.35$ with orthophosphoric acid) in the ratio of 50:50 v/v was delivered at a flow rate of $1.0 \mathrm{ml} / \mathrm{min}$ with detection at wavelength $250 \mathrm{~nm}$. The Injection volume was $20 \mu \mathrm{l}$ and the analysis was performed at ambient temperature.

\section{Standard stock solution}

Stock solutions of paracetamol and flupirtine maleate (1 $\mathrm{mg} / \mathrm{ml}$ ) were prepared separately using methanol as solvent. From the standard stock solutions, mixed standard solutions of different concentrations ranging from 650 to $1950 \mu \mathrm{g} / \mathrm{ml}$ of paracetamol and 200 to $600 \mu \mathrm{g} / \mathrm{ml}$ of flupirtine maleate were prepared by diluting with mobile phase. With the optimized chromatographic conditions, a steady base line was recorded. Twenty micro litres of each mixed standard solution was injected six times and chromatograms were recorded. The retention time of paracetamol and flupirtine maleate were found to be 3.5 and $5.4 \mathrm{~min}$, respectively. Calibration curves were constructed by plotting the average peak areas against the respective concentrations and found to be linear in

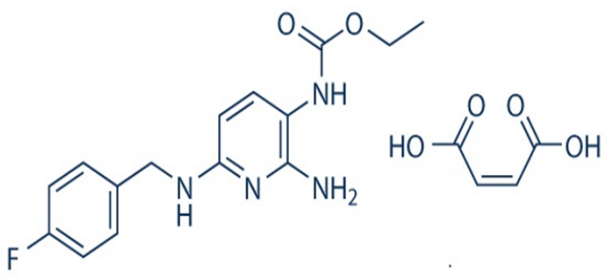

Figure 2: Srtucture of flupirtine maleate

the above range with the correlation coefficients $\left(\mathrm{r}^{2}\right)$ 0.999 and 0.999 for paracetamol and flupirtine maleate, respectively.

\section{Analysis of paracetamol and flupirtne maleate in combined dosage form}

Twenty tablets were weighed and average weight was determined and finely powdered. Tablet powder equivalent to $325 \mathrm{mg}$ of paracetamol and $100 \mathrm{mg}$ of flupirtine maleate was accurately weighed and transferred to $100 \mathrm{ml}$ volumetric flask. The contents were sonicated after adding $50 \mathrm{ml}$ of methanol and the volume was madeupto the mark with same. The sample solution was filtered through whatmann filter paper. Suitable dilutions with the diluent were made to prepare tablet solutions containing $1300 \mu \mathrm{g} / \mathrm{ml}$ ofparacetamol and 400 $\mu \mathrm{g} / \mathrm{ml}$ of flupirtine maleate. Twenty micro liters of the solution was injected into the chromatographic system and the peak areas were measured and the quantitation was carried out by keeping these values to the regression equation of corresponding calibration curve.

\section{VALIDATION ${ }^{11-12}$}

The method was validated for accuracy, precision, linearity, limit of detection, limit of quantitation and robusteness as per ICH guidelines.

\section{Linearity}

The linearity of the method was determined at six concentration levels ranging from 650 to $1950 \mu \mathrm{g} / \mathrm{ml}$ of paracetamol and 200 to $600 \mu \mathrm{g} / \mathrm{ml}$ of flupirtine maleate. The regression equation of calibration curves were $\mathrm{Y}=1069 \mathrm{x}-1243$ for paracetamol and $\mathrm{Y}=4655 \mathrm{x}$ 12538 for flupirtine maleate.

\section{Accuracy}

Method accuracy was perfomed by adding known amounts of paracetamol and flupirtine maleate to the preanalysed synthetic mixture solution and then comparing the added concentration with the found con- 
Table 1: System Suitability and Validation Parameters

\begin{tabular}{|c|c|c|}
\hline Parameters & Paracetamol & Flupirtine maleate \\
\hline Theoretical plates & 5660 & 6482 \\
\hline Resolution & ----- & 6.43 \\
\hline Tailing factor & 1.11 & 1.02 \\
\hline Retention Time (min) & 3.5 & 5.4 \\
\hline Linearity range $(\mu \mathrm{g} / \mathrm{ml})$ & $650-1950$ & $200-600$ \\
\hline $\begin{array}{l}\text { Regression Equation } \\
Y=m x+c\end{array}$ & $Y=1069 x-1243$ & $Y=4655 x-12538$ \\
\hline Slope (m) & 1069 & 4655 \\
\hline Intercept (c) & 1243 & 12538 \\
\hline Correlation coefficient & 0.999 & 0.999 \\
\hline \multicolumn{3}{|l|}{ Percent RSD } \\
\hline Intra day $(n=3)$ & 0.16 & 0.16 \\
\hline Inter day $(n=3)$ & 0.09 & 0.04 \\
\hline LOD $(\mu \mathrm{g} / \mathrm{ml})$ & 6.6 & 2.39 \\
\hline LOQ $(\mu \mathrm{g} / \mathrm{ml})$ & 21.78 & 7.96 \\
\hline
\end{tabular}

centration. Three levels of solutions were made which correspond to $50 \%, 100 \%, 150 \%$ of the nominal analytical concentration $(650 \mu \mathrm{g} / \mathrm{ml}$ for paracetamol and 200 $\mu \mathrm{g} / \mathrm{ml}$ for flupirtine maleate). Each level was made in triplicate [Table 3]. The percentage recovery in each case was calculated. As per the ICH guideline, the \%recovery must be between $98 \%$ and $102 \%$.

\section{Precision}

Precision was studied to find out intra and inter day variation in the proposed method at three different levels on the same day and on three different days, respectively. The $\%$ RSD was calculated for intra-day and interday precision was found to be less than $1 \%$.

\section{Limit of detection (LOD) and limit of quantitation (LOQ)}

Calibration curves were prepared using concentrations in the range of 650 to $1950 \mu \mathrm{g} / \mathrm{ml}$ of paracetamol and 200 to $600 \mu \mathrm{g} / \mathrm{ml}$ of flupirtine maleate (expected detection limit range). The standard deviation of $\mathrm{Y}$ intercepts of regression lines were determined and kept in the following equation for the determination of LOD and LOQ.

Detection limit $=3.3 \sigma / \mathrm{S}$

Quantitation limit $=10 \sigma / \mathrm{S}$

where,

$\sigma$ is the Standard deviation of $\mathrm{Y}$ intercept of regression lines

$\mathrm{S}$ is the slope of calibration curve

The LOD was found to be $6.6 \mu \mathrm{g} / \mathrm{ml}$ for paracetamol and $2.39 \mu \mathrm{g} / \mathrm{ml}$ for flupirtinemaleate. LOQ was found to be $21.78 \mu \mathrm{g} / \mathrm{ml}$ for paracetamol and $7.96 \mu \mathrm{g} / \mathrm{ml}$ for flupirtine maleate, respectively.

\section{Robustness}

Robustness of the method was determined by making slight changes in the composition of mobile phase \pm $2 \%$, flow rate by $\pm 0.2 \mathrm{ml}$, detection wavelength by \pm $2 \mathrm{~nm}$ and temp by $\pm 2{ }^{\circ} \mathrm{C}$. It was observed that there were no marked changes in the retention time and area of the chromatograms and the \% RSD was less than 1 $\%$, which demonstrated that the developed RP-HPLC method was robust.

\section{Specificity}

Commonly used excipients (starch, lactose, magnesium stearate etc.) were spiked into a pre weighed quantity of drug mixture. The chromatogram was taken by appropriate dilutions and the amount of each drug present the sample mixture was determined.

\section{Stability}

In order to demonstrate the stability of the both the standard and sample solutions during analysis, both the solutions were analyzed over a period of 5 hours at room temperature. The peak areas and retention time of both the drugs remained almost unchanged and no significant degradation within the indicated period.

\section{RESULTS AND DISCUSSION}

The goal of this study was to develop and validate a novel RP- HPLC method forsimultaneous analysis of paracetamol and flupirtine maleate in its bulk and pharmaceutical formulations using a commonly used reverse phase $\mathrm{C}_{18}$ column. To develop an effective method for 


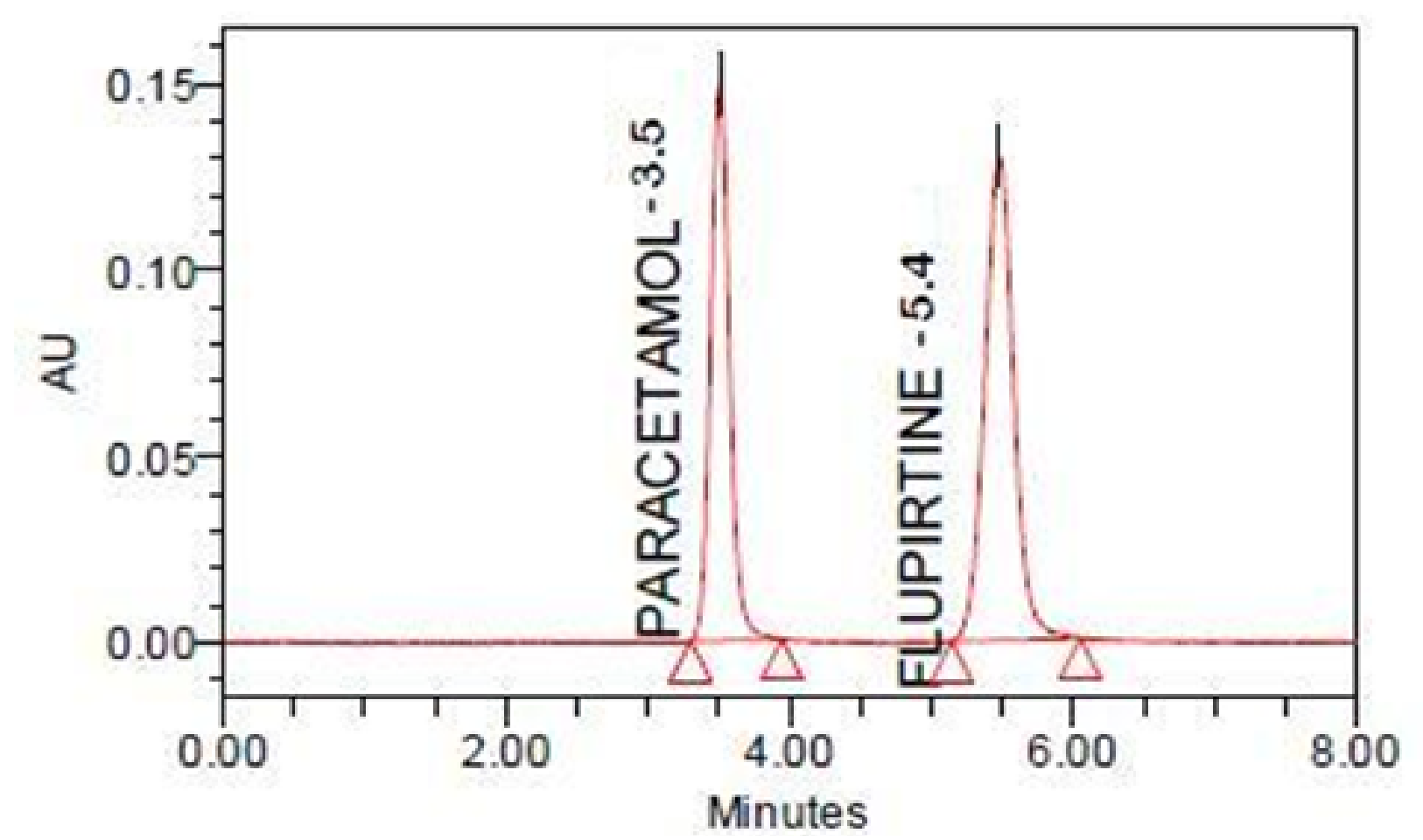

Figure 3: Typical chromatogram showing separation of Paracetamol $(1300 \mu \mathrm{g} / \mathrm{ml})$ and Flupirtine maleate $(400 \mu \mathrm{g} / \mathrm{ml})$ in combined dosage formulation

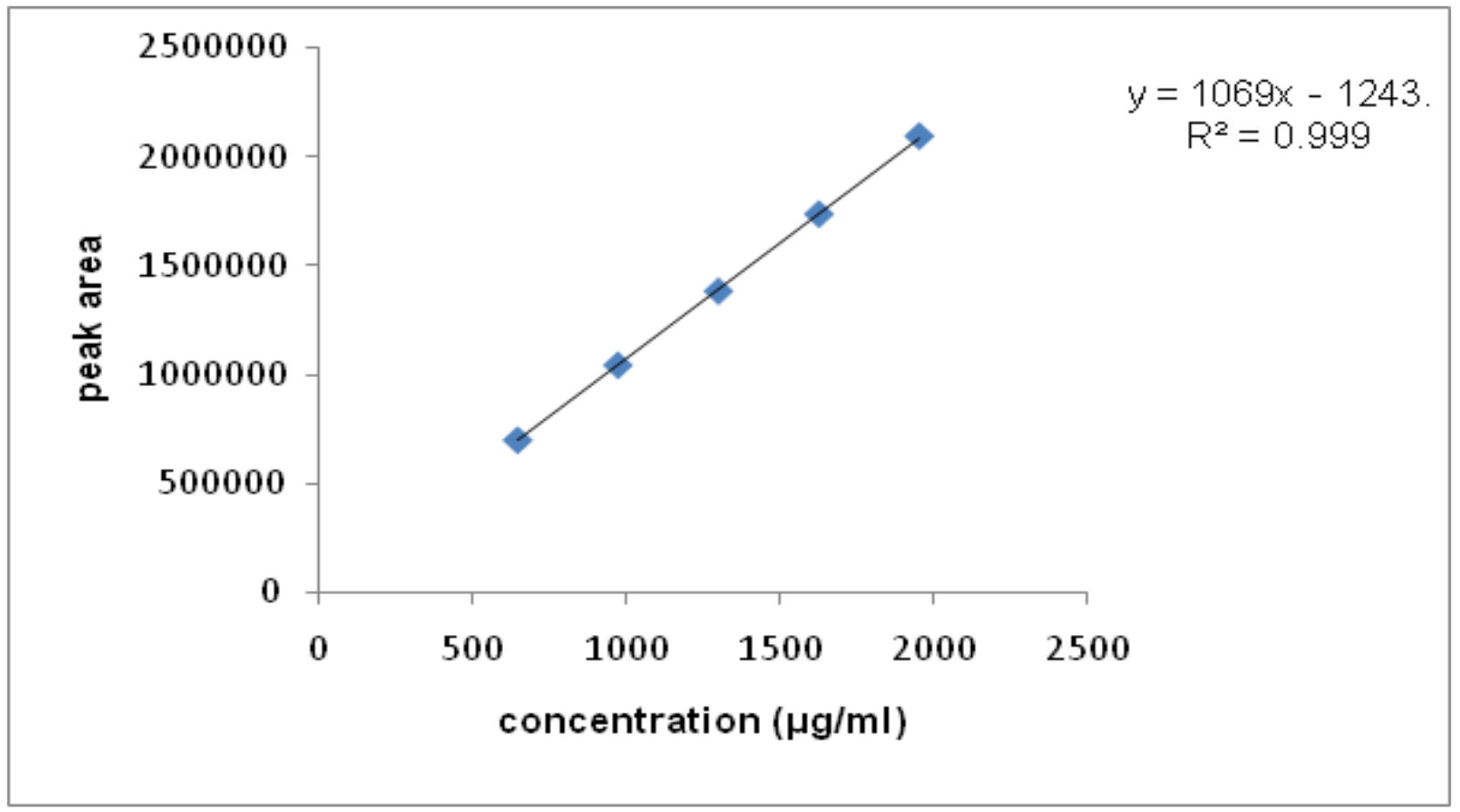

Figure 4: Calibration curve of paracetamol

the analysis of the drugs, preliminary tests were performed in order to select adequate and optimum conditions. Parameters such as detection wavelength, ideal mobile phase and its combination, optimum $\mathrm{pH}$ and concentration of the standard solution were studied. The mobile phase containing water and methanol $(\mathrm{pH}$ was adjusted to $3.35 \pm 0.03$ with ortho-phosphoric acid) in the ratio of $50: 50 \mathrm{v} / \mathrm{v}$ with a flow rate of $1.0 \mathrm{ml} /$ min was selected for analysis after preliminary tests. The retention time of paracetamol and flupirtine maleate were 3.5 and 5.4 min, respectively. Resolution between paracetamol and flupirtine maleate was found to be 6.43 , which indicate good separation of both the compounds. 


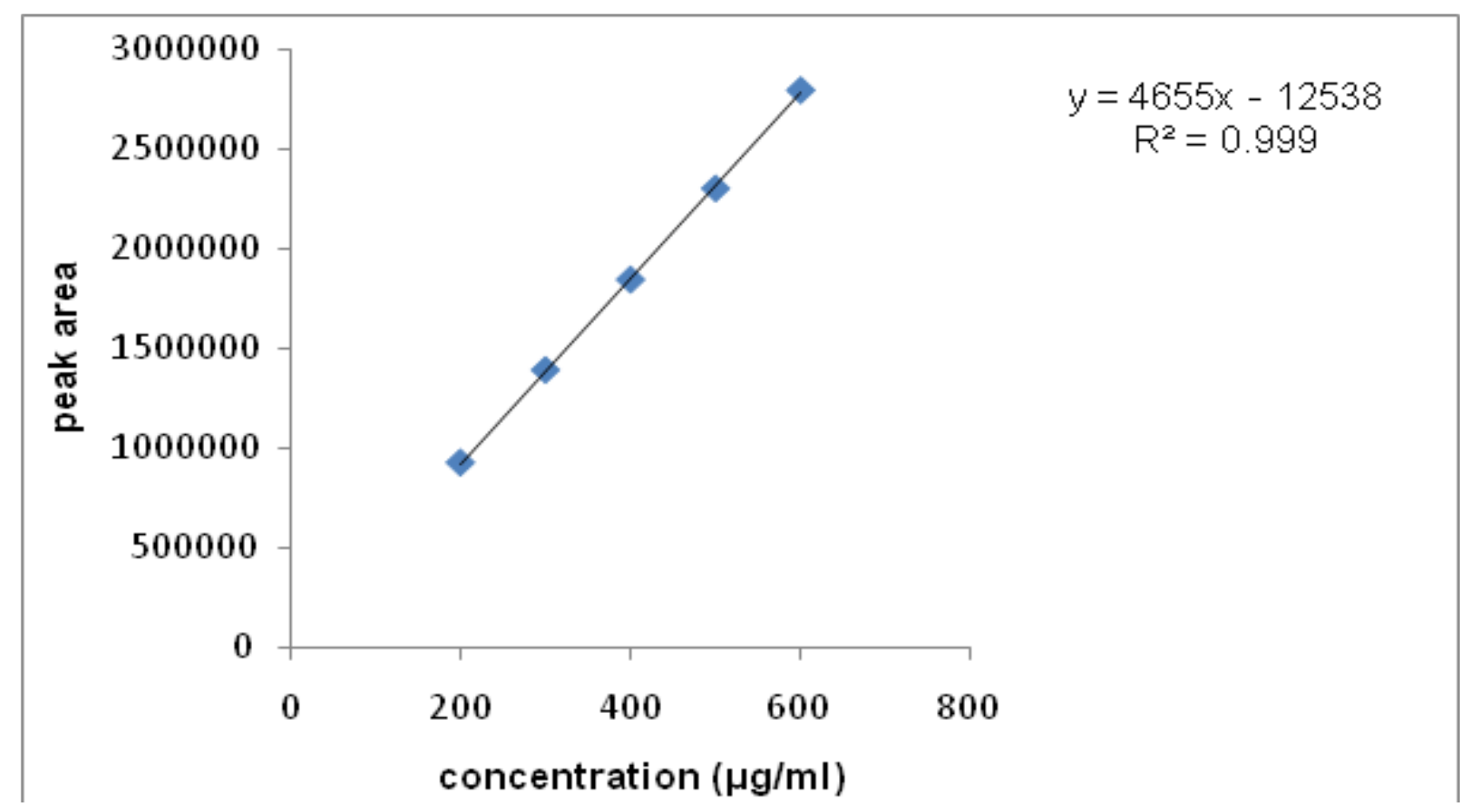

Figure 5: Calibration curve of flupirtine maleate

\begin{tabular}{|c|c|c|c|c|}
\hline \multirow{2}{*}{ Parameter } & \multirow{2}{*}{ Proposed } & \multirow{2}{*}{ Variation } & Paracetamol & Flupirtine maleate \\
\hline & & & \multicolumn{2}{|c|}{$\%$ RSD* } \\
\hline \multirow{2}{*}{ Wavelength (nm) } & \multirow{2}{*}{250} & 252 & 0.087 & 0.171 \\
\hline & & 248 & 0.068 & 0.165 \\
\hline \multirow{2}{*}{ Mobile phase } & \multirow{2}{*}{$50: 50 \mathrm{v} / \mathrm{v}$} & $48: 52$ & 0.129 & 0.175 \\
\hline & & $52: 48$ & 0.183 & 0.260 \\
\hline \multirow{2}{*}{ Flow rate $(\mathrm{ml} / \mathrm{min})$} & \multirow{2}{*}{$1 \mathrm{ml} / \mathrm{min}$} & 1.2 & 0.164 & 0.101 \\
\hline & & 0.8 & 0.154 & 0.239 \\
\hline \multirow{2}{*}{ Temperature } & \multirow{2}{*}{$30^{\circ} \mathrm{C}$} & 28 & 0.100 & 0.078 \\
\hline & & 32 & 0.120 & 0.053 \\
\hline
\end{tabular}

\section{Table 3: Results of the recovery studies}

\begin{tabular}{|c|c|c|c|c|c|}
\hline Drug & Recovery Level & $\begin{array}{l}\text { Amount added } \\
(\mu \mathrm{g} / \mathrm{ml})\end{array}$ & $\begin{array}{c}\text { Amount } \\
\text { recovered }^{*}(\mu \mathrm{g} / \mathrm{ml})\end{array}$ & \%Recovery $\pm S D^{*}$ & \%RSD* \\
\hline \multirow{3}{*}{ Paracetamol } & $50 \%$ & 325 & 324.77 & $99.83 \pm 0.11$ & 0.11 \\
\hline & $100 \%$ & 650 & 650.75 & $100.08 \pm 0.04$ & 0.03 \\
\hline & $150 \%$ & 975 & 974.50 & $99.94 \pm 0.02$ & 0.02 \\
\hline \multirow{3}{*}{ Flupirtine } & $50 \%$ & 100 & 100.09 & $100.09 \pm 0.03$ & 0.02 \\
\hline & $100 \%$ & 200 & 199.72 & $99.86 \pm 0.19$ & 0.19 \\
\hline & $150 \%$ & 300 & 300.86 & $100.28 \pm 0.36$ & 0.35 \\
\hline
\end{tabular}

\section{Table 4: Results of analysis of commercial formulation}

\begin{tabular}{|l|c|c|c|c|}
\hline \multirow{2}{*}{ Drug } & \multicolumn{2}{|c|}{ Amount mg/tablet } & \multirow{2}{*}{ \%RSD } & \multirow{2}{*}{ \%Drug estimated } \\
\cline { 2 - 5 } & Label claim & Amount found \pm SD & & 9.11 \\
\hline Paracetamol & 325 & $324.21 \pm 0.38$ & 0.16 & 100.15 \\
\hline Flupirtine maleate & 100 & $100.15 \pm 0.17$ & & \\
\hline *Average of six determinations, SD-Standard deviation
\end{tabular}


System suitability tests were carried out on freshly prepared standard solutions and the parameters are summarized in Table 1. The values obtained demonstrated that the suitability of the system for analysis of these drugs in combined dosage form. Typical chromatogram showing separation of paracetamol and flupirtine maleate is given in Figure 3. The calibration curves of paracetamol and flupirtine maleate were constructed by plotting the peak area and the drug (Y-axis) to the concentration (x-axis). It was found to be linear with a correlation coefficient of 0.999 and 0.999 which shows that good correlation exists between area of the peak and the concentration [Figure 4 and 5]. This method is validated for its intra-day and inter-day precision. The results obtained were in the acceptable limit [Table 1]. Robustness of the method was studied by changing the chromatographic conditions slightly and the results were presented in the Table 2. Detection limit for paracetamol and flupirtine maleate was $6.6 \mu \mathrm{g} / \mathrm{ml}$ and $2.39 \mu \mathrm{g} / \mathrm{ml}$ and quantitation limit was $21.78 \mu \mathrm{g} / \mathrm{ml}$ and $7.96 \mu \mathrm{g} / \mathrm{ml}$, which suggest that a microgram quantity of both the compounds can be estimated accurately. The developed RP-HPLC method in present study was used to quantify paracetamol and flupirtine maleate in combined dosage form and the results of assay were comparable with the corresponding labeled amounts [Table 4]. High recovery values and no additional peaks, in the chromatogram indicate that the proposed procedure is free from interference of the commonly used excipients in the formulation. So the proposed method is accurate and specific and can be used for routine analysis of paracetamol and flupiritne maleate in their combined dosage form.

\section{CONCLUSION}

Proposed study describes a new RP-HPLC method for the estimation of paracetamol and flupiritne maleate in combined dosage form. The method gives good resolution between the compounds with a short analysis time.
The method was validated and found to be simple, sensitive, accurate and precise.

\section{ACKNOWLEDGEMENT}

Authors wish to thank Lara Drugs Pvt Limited, Hyderabad, for providing the gift samples of paracetamol and flupiritne maleate to carry out our present work and also thankful to the management of Hindu College of Pharmacy for providing the required facilities and for their constant encouragement.

\section{REFERENCES}

1. Indian Pharmacopoeia. The Indian Pharmacopoeia Commission. Vol. 3. Ghaziabad: Govt. of India Ministry of Health and Family Welfare; 2007. p. 1514-6.

2. British pharmacopoeia. The Stationery Office on behalf of theMedicines and Healthcare products Regulatory Agency (MHRA).Vol. 2. Great Britain: The Department of Health; 2007. p. 1575-7.

3. United States Pharmacopoeia. Rockville: United States Pharmacopoeial Convention, Inc.; 2007. p. 1269-70.

4. Sean C Sweetman. Martindale: The complete drug reference. $36^{\text {th }}$ ed. London: The Pharmaceutical Press; 2009. P. 61.

5. Gopinath R, Rajan S, Meyyanathan SN, Krishnaveni N, Suresh B. A RP-HPLC method for simultaneous estimation of paracetamol and aceclofenac in tablets. Indian Journal of Pharmaceutical Sciences. 2007; 69 (1): 137-40.

6. Amal D, Aneesh TP. Method development and validation for the estimation of flupirtine maleate in bulk and pharmaceutical dosage forms using UV-VIS spectrophotometry. International Research Journal of Pharmacy. 2011; 2(12): 179-82.

7. Chen X, Zhong D, Xu H, Schug B, Blume H. Simultaneous determination of flupirtine and its major active metabolite in human plasma by liquid chromatography-tandem mass spectrometry. J Chromatogr B Biomed Sci Appl. 2001; 755(1-2): 195-202.

8. Kandasamy K, Gowdra VS, Nammalvar H, Govindarajan AK. Bioanalytical method development, validation and quantification of flupirtine maleate in rat plasma by liquid chromatography-tandem mass spectrometry. Arzneimittelforschung. 2011; 61(12): 693-9.

9. Sohan Chitlange S,, Ranjana Soni, Sagar B, Wankhede, Amol Kulkarni A. Spectrophotometric methods for simultaneous estimation of dexibuprofen and paracetamol. Asian J. Research Chem. 2009; 2(1): 30-3.

10. Wang Hai-Yang, Zhang Yan-Ling, NieLeil. Determination of flupirtine maleate capsules by RP-HPLC. Qilu Pharmaceutical Affairs. 2010; 10(10): 25-8.

11. International Conference on Harmonization. Text on validation of analytical procedures: Term and definition Q2A, International Conference on Harmonization. Geneva: IFPMA; 1996.

12. International Conference on Harmonization. Validation of analytical procedures: Methodology Q2B, International Conference on Harmonization. Geneva: IFPMA; 1997 